Impact Factor: 4.845(SJIF) Research Journal Of English (RJOE) Vol-5, Issue-1, 2020

www.rioe.org.in An International Peer-Reviewed English Journal

ISSN: 2456-2696

Indexed in: International Citation Indexing (ICI), International Scientific Indexing

(ISI), Directory of Research Journal Indexing (DRJI) Google Scholar \& Cosmos.

\title{
THE ROLE OF ENGLISH LANGUAGE TEACHER AS A FACILITATOR- A CRITICAL STUDY IN THE UNDERGRADUATE CONTEXT OF ACHARYA NAGARJUNA UNIVERSITY, GUNTUR
}

\author{
Tulluri Venkateswarlu, \\ Research Scholar,ANU,Guntur India \\ Prof M Suresh Kumar \\ Department of English, Acharya Nagarjuna University, Guntur,India
}

\begin{abstract}
The goal of this research was to study the attitudes of English language teachers of Undergraduate level in Second Language classroom at Acharya Nagarjuna University region with respect to the effectiveness of Computer Assisted Language Learning (CALL) in teaching and learning English, and to seek their views on various issues pertaining to readiness for implementation of teaching using CALL. The views of Undergraduate level teachers had not been studied prior to this research. A mixture of qualitative and quantitative approaches was used in the data collection process. The researcher designed a questionnaire and an interview to ascertain the teachers' attitudes, and also the status of computer usage in teaching English in the classrooms, and the teachers' readiness to use computers to teach English and move away from 'traditional' face-to-face methods.
\end{abstract}

This study aimed at informing stakeholders of what might be needed to empower teachers with the skills and equipment necessary for the introduction of this innovation and providing information that could facilitate implementation of computers in teaching English in Undergraduate level, in Andhrapradesh at Acharya Nagarjunal University.

The results of the research disclosed that Researcher felt that Acharya Nagarjuna University was not technologically advanced in teaching English but most teachers had knowledge about using computers and the Internet in teaching English and would welcome the implementation of computers in Undergraduate level, but overall they felt that more training and information was needed. It was found that students also have knowledge of using computers and the Internet but some did not have adequate access to either. Teachers were also concerned that there were some problems that needed to be addressed regarding the currently available CALL programs and syllabuses.

.Key words: Computer Assisted Language Learning (CALL), Training, ESL, Implementation 
Impact Factor: 4.845(SJIF) Research Journal Of English (RJOE) Vol-5, Issue-1, 2020

www.rjoe.org.in An International Peer-Reviewed English Journal

ISSN: 2456-2696

Indexed in: International Citation Indexing (ICI), International Scientific Indexing (ISI), Directory of Research Journal Indexing (DRJI) Google Scholar \& Cosmos.

Introduction

English language can give us fast communication throughout the globalization of the world. English is an official language. By learning the language, employment will be open in various professions, and highly useful in academics and social communication. Most of the official and corporate-activities run with English language.So,the role of English language for globalization is a very time concerned demand.

English is a lingua franca; it is used as a common and official language in every sector. English language is used to write every document. Now, anyone who wants to act in international discourse speaks English. It is not the language but the people who wish to communicate, use English because that's what is expected.

In several classes teachers go to the class, teach the students, supply the home task and do some daily activities and finish teaching. Instead of helping the students in learning facilitating the students in learning, is a quite fascinating and gentle concept. If a teacher thinks that every student should be sound in his subject, teaching-learning process becomes innovative, active and interesting.

Teachers should become mentors so that they should make students learn. Teaching means teacher is doing the act of teaching. Learning means students are doing the act of learning.

Facilitator - Teacher can play an important role in classroom as a facilitator. Teacher facilitates subject material, magazines, newspaper, motivational story books,etc..for the efficient learning. Teacher is a facilitator, instructor, mentor, guide and counsellor in CALL (Computer Assisted Language Learning).

The support that advanced technology, especially computers, offers to language learners and teachers has resulted in Computer-Assisted Language Learning (CALL). CALL is a new method of teaching and learning a foreign language or second language. In terms of methodology, CALL is a highly eclectic field that employs Computer-Assisted Learning Software (CALS) and borrows from Applied linguistics (Vrasidas, Georgeous, \& Papanastasiou, 2007).

CALL has become widely popular due to the impact and influence of information technology on society and education (Zaytoon, 2005). Computer-mediated courses such as CALL provide opportunities for learning in a cooperative environment, enabling learners to communicate in pairs and in groups, synchronously and asynchronously (Abu Seileek, 2009). Although CALL has been discussed widely in English as Foreign Language (EFL) literature in recent years, it remains a relatively novel concept in India at Andhra Pradesh, where learning English as a second language is limited in practice and confined to the classroom. In countries such as Japan and Singapore, CALL is the cornerstone of English teaching (Clarke 
Impact Factor: 4.845(SJIF) Research Journal Of English (RJOE) Vol-5, Issue-1, 2020

www.rioe.org.in An International Peer-Reviewed English Journal

ISSN: 2456-2696

Indexed in: International Citation Indexing (ICI), International Scientific Indexing (ISI), Directory of Research Journal Indexing (DRJI) Google Scholar \& Cosmos.

\& Gugger, 2007). The use of CALL could also benefit Indian universities if they are enabled to follow this international trend in the digital age in which technology is integrated into the education system. If this is to be achieved, Acharya Nagarjuna University teachers must be provided with state-of-the-art technology, training and resources.Computers have become common in both the personal and professional lives of citizens of India at Acharya Nagarjuna University.

Statement of the problem

English is a second language in India, even though most of the teachers and learners are using English, it is not sufficient. The teachers know the basic knowledge of computers. But language teachers and learners are not utilizing computers and materials in their professions. To develop efficient communication skills, CALL is an instrument or tool. In addition to this, English is not used in the field of administration and as a consequence it is seldom practiced in real life situations. However, after the advent of new teaching technology, the use of English could be promoted. Students of Acharya Nagarjuna University, learning the language through communicative and interactive means, such as Computer-Assisted Language Learning (CALL), could have the opportunity to interact with others.

Despite the advent of the cyber age in technology that covers all walks of life, the dominant methods and traditional methods are used. For ESL/EFL teachers at the undergraduate level, a significant impediment to use computers in teaching English is that the curriculum is based more on theory than practice. According to Fodha (2006), EFL teachers in the study area are neither qualified nor trained to use computers in teaching. Students do not have sufficient access to computer facilities, and the schools are not equipped with advanced technology and the government does not encourage schools and institutions to use computers in teaching English.EFL/ESL teachers are faced with the difficulty of teaching English to students in the Indian context of 45 minute-periods each week, with over 30 students in a class. Acharya Nagarjuna University teachers and students have facilities. But those are not sufficient .The intention of this study is to examine the most up-to-date English language teaching methods in order to improve teaching outcomes and enhance students' skills in the acquisition of English. Although interest in teaching and learning English has increased in India (Abdallah, 2005), the standard of English spoken in India remains unsatisfactory (Al Ghamdi \& Abduljawad, 2005).

Although the use of computers has been introduced, there has been no publicly available study to establish to what extent this has been or can be effective. Therefore, this research investigates whether the schools are well'equipped with appropriate technology in order to implement computer assisted language learning, as well as examining how both teachers and students feel about the use of computers in teaching and learning English. According to Fodha (2006), materials for Indian speakers of English are readily available through the 
Impact Factor: 4.845(SJIF) Research Journal Of English (RJOE) Vol-5, Issue-1, 2020

www.rioe.org.in An International Peer-Reviewed English Journal

ISSN: 2456-2696

Indexed in: International Citation Indexing (ICI), International Scientific Indexing (ISI), Directory of Research Journal Indexing (DRJI) Google Scholar \& Cosmos.

Internet via educational charts, Skype and video conferencing. These methods can improve English proficiency and acquaint users with the cultures of native English speakers, thereby opening avenues for greater understanding and communication (Erben, Ban \& Castaneda, 2008).

\section{Research questions}

The purpose of the research is to investigate the effectiveness of using computers and the Internet to teach English as a foreign language. It also aims at investigating the readiness of teachers of English at Acharya Nagarjuna University to adopt computer aided language learning and supplement and/or replace their traditional methods of teaching. This research addresses the following questions:

1. What are the beliefs and attitudes of teachers pertaining to the teaching of English in India at Acharya Nagarjuna University?

2. How can the teachers adopt their current, traditional methods of teaching to include CALL in teaching English?

3. How can CALL be effectively implemented in the Acharya Nagarjuma University to undergraduate students?

4. What are the constraints for the implementation of CALL in Acharya Nagarjuma University?

\section{Significance of the research}

The undergraduate students of Acharya Nagarjuna University not only need to develop proficiency in English communicating skills, but also have a sound understanding of the context in which the English language is used. The traditional method of teaching has failed to meet this need (Alshumaimeri, 2008). This research investigates whether CALL could provide students with a more effective method of learning the English language through the use of computers and the Internet. It is anticipated that the results of the study could help the educational administrators of the Acharya Nagarjuna University to devise teacher training programs and introduce reforms in the curricula. The results of the study could provide information that may alter the perception of educational administrators and technical supervisors in regard to the use of CALL in teaching English language, contributing to computerized teaching becoming more accepted.

Participation in the study could encourage the teachers of English and undergraduates to update their skills in the use of computers in English teaching and learning. Proficient teachers in English could make use of the results of this research in training new teachers. The results and data collected from teachers' interviews could be used by syllabus designers 
Impact Factor: 4.845(SJIF) Research Journal Of English (RJOE) Vol-5, Issue-1, 2020

www.rjoe.org.in An International Peer-Reviewed English Journal

ISSN: 2456-2696

Indexed in: International Citation Indexing (ICI), International Scientific Indexing (ISI), Directory of Research Journal Indexing (DRJI) Google Scholar \& Cosmos.

to design courses that respond to student needs. The results obtained from this study may provide efficient skills. If the results show that CALL is effective and it is then implemented and students have the opportunity to speak with native English speakers at times of their own choosing, they could change from being foreign learners to greater capacity to be able to communicate easily and fluently in English whenever they wish, both within the country and in the outside world (Alurani, 2005)

\section{Research tools}

This research uses mixed methods (quantitative and qualitative). There are 20 items within the questionnaire and 7 questions concerning the interview that the respondents answer within the context of the study. The sample consists of 60 ESL/EFL teachers within the study area at Acharya Nagarjuna University (30 Men,30 Women) for the questionnaire and 30 for the interview ( 30 men and 30 women).

Literary reviews:

Cobb. K. J. (2002). Facilitating second language acquisition through computer-assisted learning. Artmanuscript, 1(1). Gruba, G. (2004). Computer-assisted learning (CALL). In A. Davies \& C. Elder (Eds.), Handbook of Applied Linguistics, pp. 623-648. Oxford, England: Blackwell. Hamka, Prof. Dr. (2007). Computer-assisted learning method in teaching writing for junior high school school students. Jakarta, Indonesia: Universitas Muhammadiyah. Retrieved from The Effect of Computer-assisted learning (CALL) on Immediate and Delayed Retention of Vocabularies generally English Course. Mozhgan Sedaghatkar Vocabulary learning is important for language acquisition; however, it's considered problematic for the second language learners. As an educator of General English Course, I witness majority of scholars state that "It's difficult on behalf of me to recollect long words", "I rapidly forget new words", "I frequently repeat words", etc. As a matter of fact, learning vocabulary is one among the foremost boring tasks that language learners face with. Hence, alternative ways are tried towards making vocabulary learning easier. during this regard, recent years have shown an interest in using computers for foreign teaching and learning.

Overview of the research process

\begin{tabular}{|l|l|l|l|}
\hline Phase & Goal & Research method & Description \\
\hline 1 & $\begin{array}{l}\text { To assess the teachers' } \\
\text { attitudes towards updating } \\
\text { their methods by using } \\
\text { CALL. } \\
\text { To investigate the potential } \\
\text { of the Acharya Nagarjuna }\end{array}$ & $\begin{array}{l}\text { A) Destionnaire } \\
\text { questionnaire related to } \\
\text { the objective of the study } \\
\text { and giving the } \\
\text { participants a chance to } \\
\text { choose what they are } \\
\text { satisfied with. }\end{array}$ \\
\hline
\end{tabular}


Impact Factor: 4.845(SJIF) Research Journal Of English (RJOE) Vol-5, Issue-1, 2020

www.rjoe.org.in An International Peer-Reviewed English Journal

ISSN: 2456-2696

Indexed in: International Citation Indexing (ICI), International Scientific Indexing (ISI), Directory of Research Journal Indexing (DRJI) Google Scholar \& Cosmos.

\begin{tabular}{|l|l|l|l|}
\hline $\begin{array}{l}\text { University undergraduate } \\
\text { students for implementation } \\
\text { of CALL. }\end{array}$ & $\begin{array}{l}\text { B)Chi-squared for data } \\
\text { analysis }\end{array}$ \\
\hline 2 & $\begin{array}{l}\text { To investigate the level of } \\
\text { support among teachers for } \\
\text { the implementation of } \\
\text { CALL. } \\
\text { To assess attitudes towards } \\
\text { CALL in greater depth and } \\
\text { relate them to learning } \\
\text { theories. }\end{array}$ & $\begin{array}{l}\text { Semi-structured } \\
\text { Interview }\end{array}$ & $\begin{array}{l}\text { A)Verbal answering by } \\
\text { recording on tape and } \\
\text { transcribing the verbal } \\
\text { data into written data } \\
\text { B) Frequency tables for } \\
\text { data analysis. }\end{array}$ \\
\hline
\end{tabular}

Teachers' attitudes to the implementation of CALL, and the quantitative method employ variables to describe what is actually happening. The variable may be a construct or property in which the researcher is interested, such as age or gender (Cohen, Manion \& Morrison, 2007). A quantitative variable may change in degree and amount. To investigate the possibility of implementing CALL in India at Andhra Pradesh, variables such as age and gender were taken into account, using population and sampling procedures covering gender, age and educational level. In this study, the questionnaire covered teachers and students 30 men and 30 women, with ages ranging from 21 to 55 years, while the interviews covered 30 men and 30 women in the same age bracket. This method provides definitive data that can be modelled statistically. The method also can help to reduce the researcher's bias, provided that the results are interpreted dispassionately (Wiersma, 2000). Questionnaires can be administered to a sample population and the statistics generated from these results can be taken as being representative of a larger population, provided that the limitations of the sampling technique are accounted for (Hatch, 2002; Wiersma, 2000).

\section{Data analysis}

Analysis of pre-test and post-test performance:

To know their language proficiency three tests have been conducted, they are pre-test, while test and post test.Analysis of pre-test, while -test and post-test performance 
Impact Factor: 4.845(SJIF) Research Journal Of English (RJOE) Vol-5, Issue-1, 2020

www.rioe.org.in An International Peer-Reviewed English Journal

ISSN: 2456-2696

Indexed in: International Citation Indexing (ICI), International Scientific Indexing (ISI), Directory of Research Journal Indexing (DRJI) Google Scholar \& Cosmos.

Pre-test-results

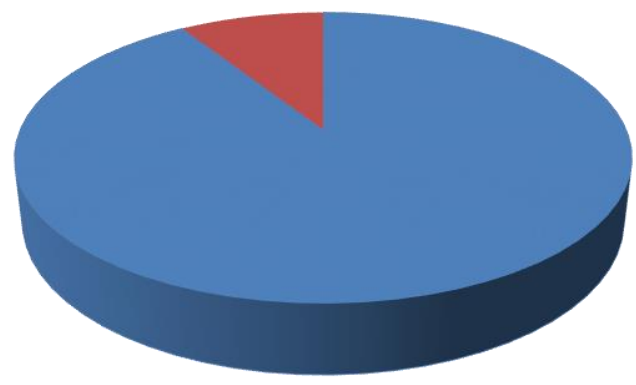

target level

students language proficiency at pre-test

Acharya Nagarjuna University undergraduate students participated in pre- test. Their language proficiency is very low comparing to target level of proficiency. Their language proficiency is 31 percentage at pre- test. Here, in the above picture, Blue colour indicates that students' that much of language proficiency has to be improved. Brown colour shows that the present level of students' language, that is at 31 percentage. They have to reach at least 85 to 95 percentage. Based on their needs, designed materials are used, it has taken almost three months to complete the target.

While test- results

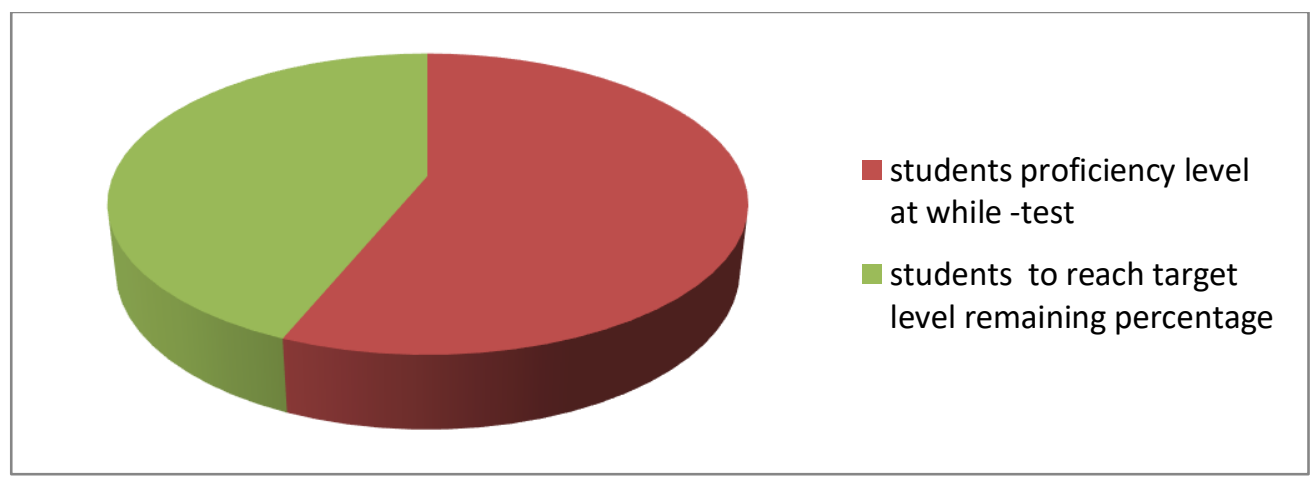

The brown colour indicates that students' language proficiency reached to $60 \%$. Green colour shows that students have to learn the language gap of percentage. The selected teaching materials are used while students are practicing the tasks; therefore, the improvement has come from 31 percentage to 60. The students understand that practicing of the tasks will help to reach the target level.

Students' post-test results 
Impact Factor: 4.845(SJIF) Research Journal Of English (RJOE) Vol-5, Issue-1, 2020

www.rioe.org.in An International Peer-Reviewed English Journal

ISSN: 2456-2696

Indexed in: International Citation Indexing (ICI), International Scientific Indexing (ISI), Directory of Research Journal Indexing (DRJI) Google Scholar \& Cosmos.

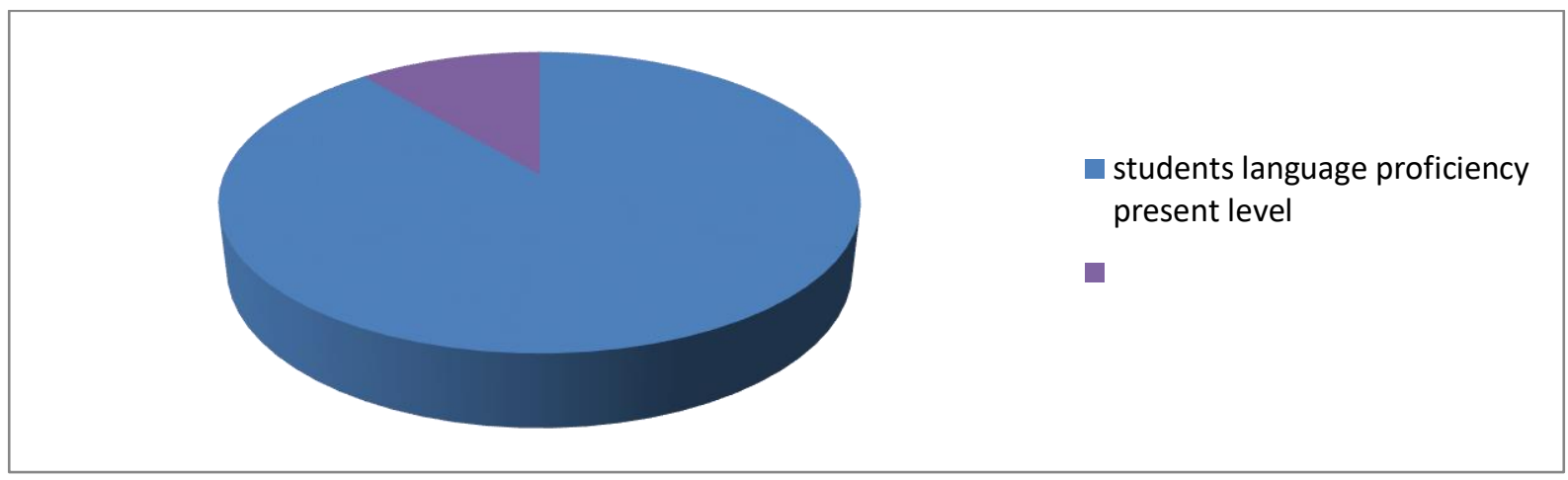

Finally the students have reached the target level. Language proficiency at pre- test is 31 percentage, that has reached 60 percentage in while test, and in post test, the students' language proficiency has reached 95 percentage. Designed and selected materials were highly useful for the students. At present, students can communicate efficiently in their profession, academically and socially by applying CALL (computer assisted language learning).

\begin{tabular}{|l|l|l|l|}
\hline 1 & pre-test results & while test results & post test -results \\
\hline 2 & 3.399 & 6.111 & 8.99 \\
\hline
\end{tabular}

The undergraduate students of Acharya Nagarjuna University reached from present level to target level. From every test the development has come in their communication skills.

\section{Conclusion}

The researcher finds out that (CALL) Computer Assisted Language Learning brought excellent results in teacher development as well as student skills. The findings and recommendations may help push the wheel of development forward in the field of English language teaching and learning in the area of teacher development and undergraduate students communicational skills. The recommendations, together with the findings, are relevant for all those concerned with the profession of teaching, starting from the top administration, represented by the Ministry of Education, to those represented by the local administrative units and school administrations, through the teachers as front-line educators. The researcher also hopes to encourage an endeavour in the universities of Acharya Nagarjuna University to gear research and the teaching of education and language students towards this new field, to participate in the ongoing education of teachers to enable them to be competent in exploiting computers for the purpose of English language teaching and learning. 
Impact Factor: 4.845(SJIF) Research Journal Of English (RJOE) Vol-5, Issue-1, 2020

www.rioe.org.in An International Peer-Reviewed English Journal

ISSN: 2456-2696

Indexed in: International Citation Indexing (ICI), International Scientific Indexing (ISI), Directory of Research Journal Indexing (DRJI) Google Scholar \& Cosmos.

\section{References:}

- Almousa., A,A . (2008). Using computer in education. King Abdullah library: Riyadh, Saudi Arabia.

- Brown, H. D. (2007). Teaching by principles: An interactive approach to language 215 pedagogy (3rd ed.). White Plains, NY: Pearson Education.

- Cobb. K. J. (2002). Facilitating second language acquisition through computerassisted language learning. Artmanuscript, 1(1). Cohen, L., Manion, L. \& Morrison, K. (2007). Research methods in education (6th ed.). London: Routledge.

- Duffy, T. M. \& Jonassen, D. H. (1992) Constructivism and the technology of instruction: A conversation. Hillsdale, NJ: Lawrence Erlbaum Associates. Egbert, J., Hanson-Smith, E. \& Huh. K. (Eds.) (2007). CALL environments: Research, practice and critical issues (2nd ed.). Alexandria, VA: TESOL. Ellis, R. (1985). Understanding second language acquisition. Oxford, England: Oxford University Press.

- Taylor, S., \& Todd, P. A. (1995). Understanding information technology usage: A test of competing models. Information Systems Research, 6(2), 144-176. Torlakovi, E. \& Deugo, D. (2004). Application of CALL system in the acquisition of adverbs in English. Computer-assisted Language Learning. 17(2), 203-235.

- Skinner, D. (2010). Effective teaching and learning in practice. London: Continuum International. Smith, D. D. (2004). Introduction to special education: Teaching in an age of opportunity. Cranberry, NJ: Pearson Education. Sun, Y. H. S., (2011). Online language teaching: The pedagogical challenges. Knowledge management and elearning: An international journal, 3(3), 428-447.

- Zorko, V. (2009). Factors affecting the way students collaborate in a wiki for English language learning. Australian Journal of Educational Technology, 25(5), 645-665. 